\title{
Forest functions and space: a geohistorical perspective of European forests
}

Roberto Pilli (1), Andrea Pase ${ }^{(2)}$

(1) European Commission, Joint Research Centre, Directorate D - Sustainable Resources - Bio-Economy Unit, Ispra, VA (Italy); (2) Università di Padova, Dipartimento di Scienze Storiche, Geografiche e dell'Antichità, Padova (Italy)

@ Roberto Pilli (roberto.pilli@ec.europa.eu)

Received: Dec 15, 2016 - Accepted: Nov 21 2017

Citation: Pilli R, Pase A (2018). Forest functions and space: a geohistorical perspective of European forests. iForest 11: 79-89. - doi: 10.3832/ifor2316-010 [online 2018-01-31]

Communicated by: Luca Salvati
The history of man has been linked to the history of wood since prehistoric times and because the forest is the main place where this resource is available, forest spaces are also directly linked to the evolution of human society. The objective of this paper is to analyze the historical evolution of the functions assigned by humans to forests, highlighting how they affect the production of space from a diachronic perspective. Focusing our attention on some European countries, we highlight that although historically, wood production was the most important function provided by wooded lands, other functions were also attributed to forests. The awareness of these functions emerged when an overexploitation of forest resources produced a lack of a specific service. When these services corresponded to a societal demand, they produced welfare benefits for the society, which were recognized as forest functions. Thus even the functions evolved in time according to the evolution of societal needs. Evaluating when and how each societal demand emerged, and consequently the moment each function was recognized, is an essential prerequisite even for a more accurate interpretation of current forest management practices. Not only is the temporal dimension of forest functions relevant, so is the spatial scale, which may differ considerably between them, ranging from the specific forest area and its owner for the productive function; to the catchment area and its inhabitants for the protective function; to a potentially larger area for the cultural and biodiversity function; and to the entire globe for the carbon-retention function. The strict, and sometimes competing, interactions between these functions may also be recognized in the production of space, which evolved in time according to the evolution of the corresponding societal needs. A forest parcel assigned to a productive function is a material space, marked in the field by colored signs, but it may also be virtually represented by a forest model or be part of some protected area. But this picture would change if, instead of looking at the present, we consider the past and the different sensations and representations concerned with forests. These complex interactions, between different functions and spatial dimensions, justify the need to balance a segregative management system with a wider, multifunctional integrated approach. What has emerged from our study is that to reach this difficult equilibrium, it is useful to consider the production processes of these forest spaces. Through this analytical approach, we can understand the interactions occurring over time between the evolution of the demands expressed by society and the main changes occurred on the forest landscape.

Keywords: Forest Functions, Services, Production of Space, History, Sustainable Forest Management

\section{Introduction}

The history of man has been linked to the history of wood since prehistoric times and since the forest is the main place where this resource is available, the forest space is also linked to the evolution of human society (Rackham 1986).

From prehistoric wooden tools (Mourre et al. 2010), to the use of wood for fire (May-Tobin 2011) and for building, until the most recent consideration of wood for carbon storage (Pilli et al. 2015), the forest space has always provided some product or service to man. Even if these benefits were generally and for a long time "collected" without any social awareness, the forest has long been recognized as a spe- cific and distinct area, which was gradually modified in order to satisfy human needs. To use the words suggested by Lefebvre (1974): over time societies realized a "production of the space". In the specific case of forests, this space changed over time, according to the change of the forest functions. This mutual interaction, between space, function and human society, already highlighted by contemporary human geography (Harvey 2006), was rarely considered for the forest space.

Until the beginning of the $20^{\text {th }}$ century, the term "function" was seldom used, being often replaced with different terms such as "profits". After the Second World War, Dietrich described the interaction be- 
tween forests and man using the term "benefits", defined as some natural effects provided by the forest and useful for man. He coined the term "forest function" to describe the benefits that fulfill a societal demand (Riegert \& Bader 2010). Concepts and definitions of forest functions and benefits were, and still are, much debated, above all in German academic circles (see for example Pistorius et al. 2012, for a recent overview), but three broad groups of functions have generally been considered: (i) the productive (or utility) function, focusing on the economic utilization of forest resources; (ii) the protective function, in cluding the totality of physical, chemical and biological effects of the forests within the scope of the natural environment; and (iii) the recreation function, including the effect of the forest on human wellbeing (Krott 2005). As indicated by Pistorius et al. (2012), these well-established definitions may be intersected with the concept of ecosystem services (ESs), as expressed in the Millennium Ecosystem Assessment (MA 2005). According to this definition, any given ecosystem includes a fixed stock of capital that can provide a variety of ben efits to society, and ESs represent the bridge between these two spheres interacting with each other.

Although this theoretical framework has been widely adopted, the European Environment Agency recently proposed a Com mon International Standard for Ecosystem Services (CICES), whose purpose was to reconcile all the possible definitions and to account for local relationships between ecosystems and society (Haines-Young \& Potschin 2011). For the purpose of CICES, ESs are defined as the contributions that ecosystems make to human well-being, dis tinguishing three major themes: (i) provisioning, (ii) regulating and maintenance and (iii) cultural. Each of these themes in cludes different classes. For example, from a forest perspective, the provisioning service includes the material class, which in cludes in turn, raw materials production that is mainly represented by wood.

Of course, all forests contain trees that could provide wood for different material uses, protection against water and wind erosion or some cultural and social benefit. Depending on societal needs, however, some of these services may be completely ignored while all the attention may be focused on one specific function. Because of the complex interaction between these benefits, forest management can maximize one function and reduce or cancel another. Today, at least at the European level, mod ern forest management tries to balance different services while taking into account these complex interactions and the need of our society. This approach, considers the forest as a "multi-functional" system (State of Europe's Forests 2015). This may be seen as an attempt to define the optimal use of forest resources for the com mon welfare of the people (Krott 2005).
But, what was the attitude in the past? Can we simply assume that there was no awareness of these functions and a passive use of these resources? And, if so, when and why did this attitude change? Since the functions and benefits attributed to forests respond to societal demands at certain times, it is clear that these functions may change according to the economic and social context.

The evolution of forest functions has effects also on the social production of the forest space. Space, in this case, is not intended as an objective and immutable element but rather, as suggested by Lefebvre (1974), as something that is strictly related to the social context. Indeed, according to Harvey (2006), apart from the absolute space, defined and measurable through Euclidean geometry such as the polygon defining a forest parcel, we can identify other spaces, strictly linked to social and power dynamics. These include the relative notion of space, measured in terms of time or costs, and the relational concept of space, embedded in social, political, economic and cultural relationships. Since each forest function may have specific effects on the production of space, we can also highlight the evolution of the forest spaces through a diachronic analysis of these functions. What was in the past, and is now, the relationship between forest functions and the social production of forest spaces?

Leaving aside the complex debate on ESs and forest function definitions, widely treated in the literature (Krott 2005, Riegert \& Bader 2010, Haines-Young \& Potschin 2011, Pistorius et al. 2012), and taking into account that forest scientists often neglected historical forest functions in the pre-industrialized society, such as the complex interactions between these functions and the forest space, the objective of this paper is to analyze the historical evolution of the functions assigned by humans to forests, highlighting how they affected the production of space.

\section{Methodological assumptions}

Given the complexity of defining the ESs and ecological functions, the use of multiple classification systems is still probably necessary (Haines-Young \& Potschin 2011). For example, the "supporting services" such as soil formation, photosynthesis and nutrient cycling, originally considered by the MA as an independent ES, are considered by the CICES as part of the process and functions that characterize each ecosystem. Given these differences and the dynamic nature of this process, we consider, in addition to the main groups of forest functions traditionally taken into account by forest science (productive, protective and cultural), other categories (biodiversity and carbon retention), which meet specific demands of modern society. An overview of these functions is reported in Fig. 1, highlighting, on the horizontal axis, the historical evolution of each one and, with the arrows on the right, the potential competition between them. At the same time, the two terms, functions and services, will not be strictly distinguished in the following pages, but further discussed at the conclusion of the analysis, taking into account the historical perspective suggested by our study. In the next sections, each function is analyzed from a diachronic point of view in an attempt to identify the roots of the functions attributed to the forest by modern society and the resulting effect on the production of space. Indeed, this process evolves over time according to the changes in knowledge, technical capabilities, economic interests, and levels of human pressure. In addition, while certain features were already present and important in ancient times and it is therefore possible to identify their evolution over time, others appeared in recent times (e.g., carbon storage-sink) or only assumed a particular role in modern times (e.g., biodiversity). Due to the potentially wide scale of this subject, the analysis is mainly focused on Italy and Central European countries.

Depending on the favored forest function, we may even detect different effects on the production of space but, since different functions generally coexist in the same area and result from the overlapping of past and present functions over time, the effect on the space will be due to the complex and sometimes conflicting interactions between these functions.

In the geographical disciplines, the production of space is considered as a key category to understand the mutual relationships between human society and the environment, such as the power dynamics within a social system and between different human groups within and between societies (Harvey 2006). As highlighted by Lefebvre (1974), each society produces its own space and, following Marx's theories, the production of space embodies the power relationship of a given society (Gottdiener 1993, Brenner \& Elden 2009). Lefebvre considers the production of space under three different points of view, named as dimensions: the material space; the representation of space; and the space of representation. The first one is a concrete space and is linked to the material experiences directly perceptible by our senses. The second, the representation of space, is linked to the way we think and represent a space whether it be through maps, words, graphs, pictures, etc. The third space, which is the space of representation, is linked to how the space is perceived, i.e., the lived space, including the emotions (e.g., fears or wishes), imaginations (e.g., expectations and fantasies) and sensations produced by the space in everyday life.

Through this conceptual triad we can identify different dimensions for the forest spaces: a forest parcel is a material space that can be represented through a forest map and may produce different emotions, 


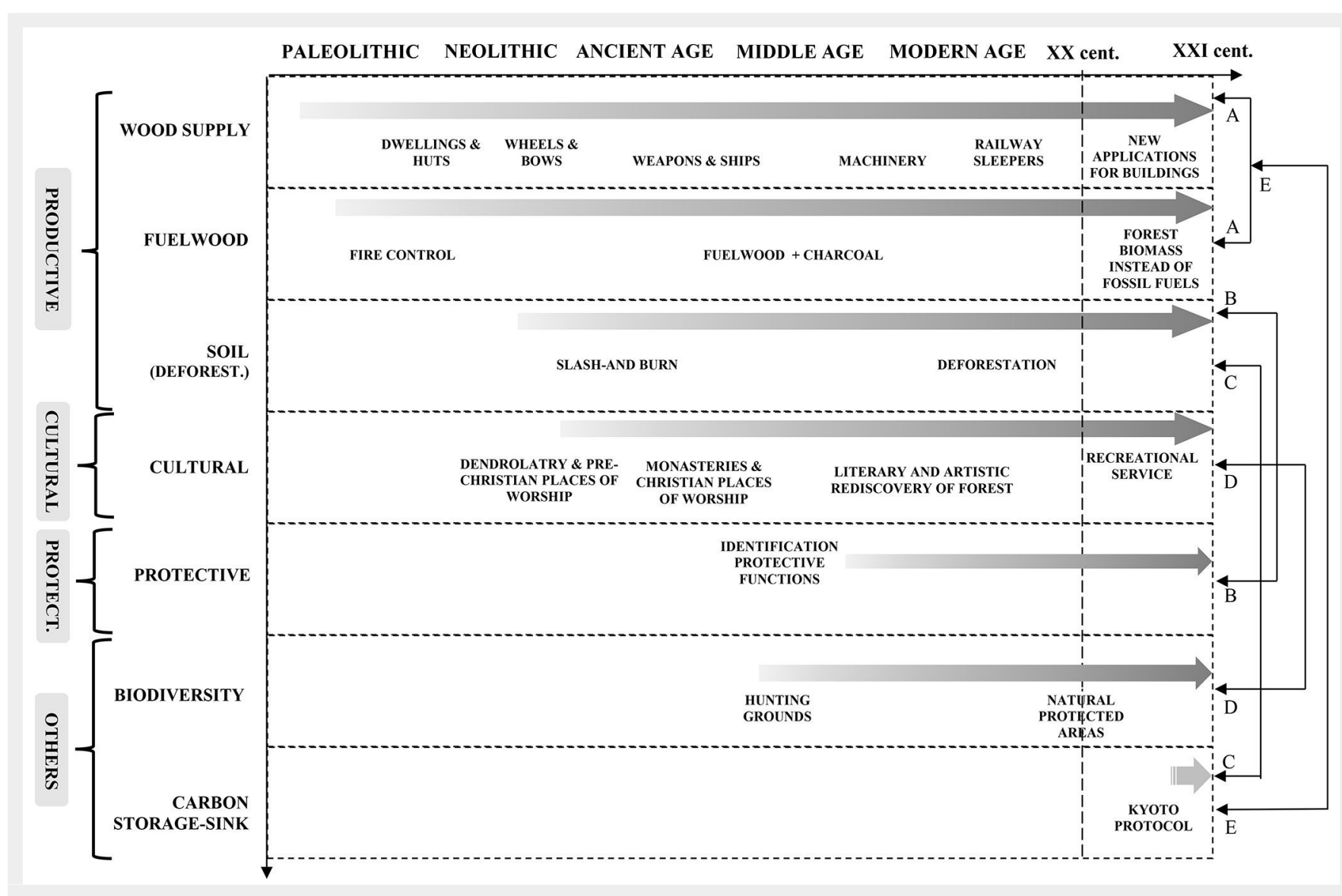

Fig. 1 - The figure schematizes the historical evolution of the main functions attributed to forest (on the $y$ axis), over time (on the $x$ axis) and their main links (in $21^{\text {st }}$ century society), highlighted by the arrows and letters on the right. Apart from the main groups of forest functions, traditionally considered in forest science (productive, protective and cultural) we also added a fourth group (others), including subcategories (biodiversity and carbon) that answer specific demands of modern society. The grey graduated arrows highlight the continuity over time of each forest function. Detailed explanations are given in the text.

such as fears or wishes, linked to the specific attitudes of each individual or human society. The space production may have different effects not only due to the actors involved in these processes, but also in relation to the purposes of each actor, i.e., the function attributed to the forest space. Tab. S1 in the Supplementary Materials summarizes, for each forest function, some of these effects on the forest space, focusing mainly on the material space and the representation of space. Due to the potentially broad aspects involving the space of representation of the forests, i.e., the emotions, imagination and sensations that the forest environment has produced in the past, and still produces, in our everyday life, this aspect will only be mentioned in the present work.

\section{Historical and spatial evolution of functions and forest spaces}

In the following sections, the historical evolution of each forest function, as introduced in Fig. 1, is analyzed together with its main effects on the production of space, as summarized in Tab. S1 of the Supplementary material.

\section{Productive functions}

This category includes all the wood re- moved from the forests and used as timber and as fuelwood, plus other possible material uses of forest resources (i.e., cork). According to the CICES classification system, these functions are grouped under the provisioning theme, including both the materials and energy service class. Since these two products represent the main, sometimes competing, use of forest resources they will be considered as two different functions.

\section{Timber production}

Prehistoric wooden tools probably represent the first use of wood by humans (Mourre et al. 2010) even if the prehistoric objects made of wood are extremely rare, due to the unfavorable preservation conditions (Nadel et al. 2006). Apart from these objects, including furnishings and simple weapons, since Neolithic times wood was essential for building huts, pile dwellings and more complex buildings.

Detailed descriptions of the forest species used for producing different tools and furnishings, such as poles, plows, weapons and statues, are reported by many Latin authors such as Vitruvius and Theophrastus (Di Bérengher 2010). More recently, some authors described the historical utilization of different tree species for the manufac- ture of specific tools in regions such as Great Britain and Moravia (e.g., Rackham 1986, Filková et al. 2015). Apart from these, one of the most relevant uses of wood was for wheels and boats. Around 3,000 BC, the invention of the wheel, consisting of a solid wooden circle constructed by three planks fastened together, revolutionized human transport in the Euro-Asiatic area (Diamond 1997). Possibly even more important was the use of wood for navigation. Indeed, for any society and until the $19^{\text {th }}$ century, wood was an essential raw material, not only for building transport ships but, above all, for war activities. Examples include the Peloponnesian War, Punic Wars, the Spanish Invincible Armada (Wing 2015) or the Venice Republic (Di Bérengher 2010). This huge demand for timber led to increasing pressure on forests. The most discerning governments began protection policies for forest spaces. For example, in the $14^{\text {th }}$ century, the Venetian Senate promulgated specific laws to guarantee a continuous supply of oak and beech wood for the Venetian shipyards (Cacciavillani 1984). This had a direct and increasing effect on the forest space, since some of the most important forested areas of the Venetian territory (such as the Cansiglio plateau or Montello hills) were identified, delimited, 


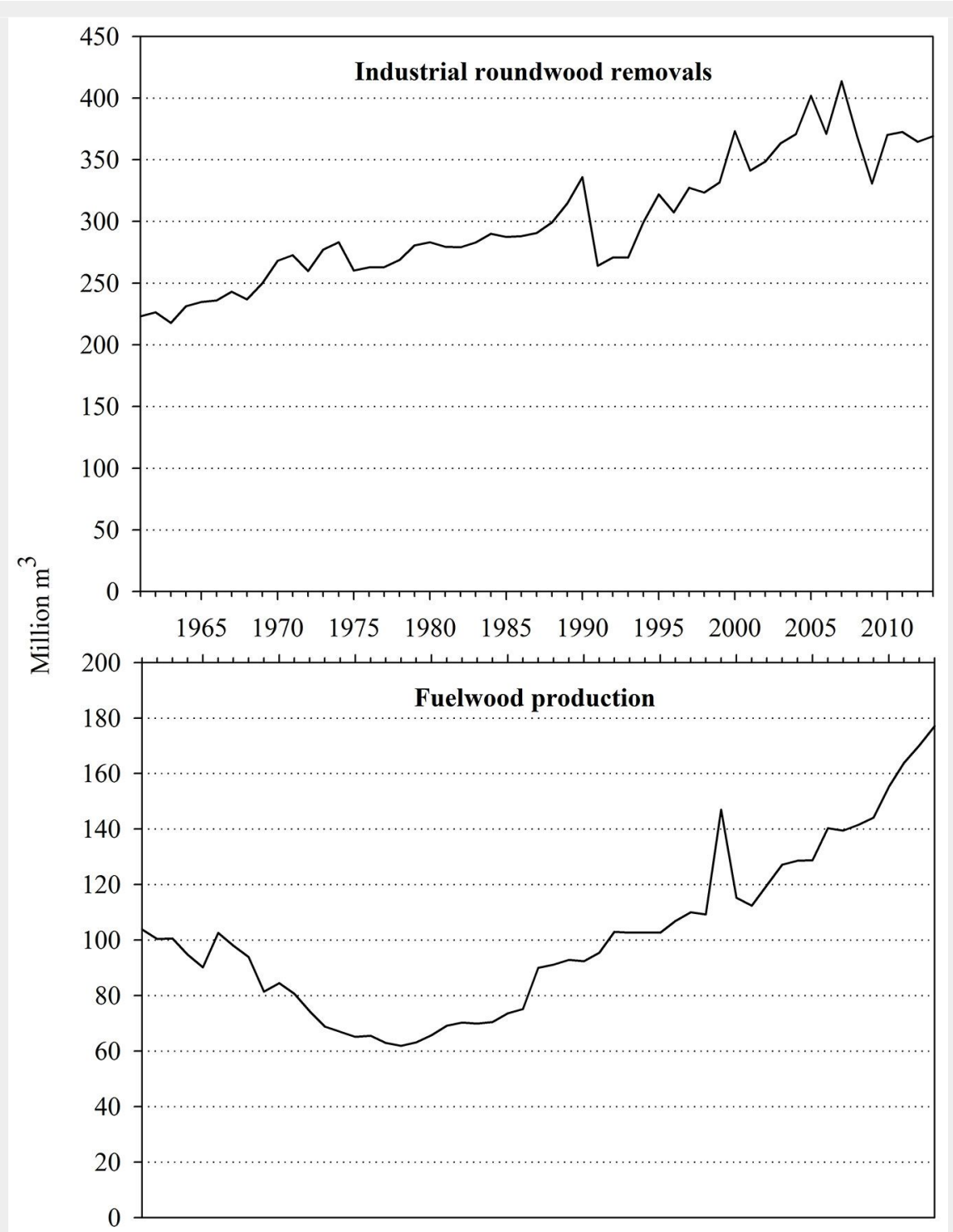

Fig. 2 - The upper panel reports the industrial roundwood removals from forests in Europe from 1960 to 2012, in million cubic meters per year (excluding former USSR). The crash in 1990 is due to the economic consequences of the collapse of the former USSR. The peaks in 1999, 2005 and 2007 are indirect effects of large wind storms affecting European forests during these years. The lower panel reports the fuelwood production for the same area and period. Source: elaboration FAOSTAT (2015).

and mapped to preserve these resources (Casti Moreschi \& Zolli 1988).

The role of wood was also essential during the Industrial Revolution: (i) directly, for building frames and waterwheels; and (ii) indirectly, in the fifteenth and the sixteenth century, when in England the lack of fuelwood and charcoal stimulated the use of coal, that reduced the cost of energy and, at the end, this created a demand for technology that substituted energy for labor (Allen 2009). But even when coke replaced fuelwood and steel replaced wood for building ships and steam engines, an alternative demand for poles, needed for mines and railway sleepers, gave a new impulse to harvesting activities (Mokyr 1992). To satisfy this demand, starting in the most developed German regions (Prussia and Saxony) between the $18^{\text {th }}$ and $19^{\text {th }}$ century, scholars laid the foundations for the so-called modern forest sciences (Ciancio 2014). Following the "high-modernist" principles in the most economically advanced European countries, forests became an economic resource to be managed efficiently and profitability in order to maximize wood production (Scott 1998). During the $19^{\text {th }}$ and $20^{\text {th }}$ centuries, these new practices largely changed and simplified the original space and composition of many European forests, above all in central Europe where broadleaves were gradually replaced by conifers (mainly spruce), while the original mixed, uneven-aged forests were replaced by pure, even-aged forests. Where this phenomena took place, the forest space was geometrically divided into roughly equal plots, named forest parcels. These were carefully measured, mapped and marked in the field by different colors and numbers and grouped into larger forest compartments, managed by specific forest plans. The theoretical, and at the same time practical consequence on the material space was planting simultaneously in straight rows through seeding. Clear-cutting the entire parcel was the gradual replacement of the original "chaotic" forest with a new, uniform space (Scott 2010), assuming the appearance of the "pure evenaged high forest", as defined by modern forest science.

This system was predominant until the Second World War, but due to the long lifecycle of the forest (generally greater than 100 years), the current forest space in many European countries still largely reflects this management model, with a focus on the productive function attributed to the forest. From the middle of the $20^{\text {th }}$ century, the biological limits of this system, which increased the long-term vulnerability of the trees to natural disturbances and the new needs of the society, forced foresters to adopt other management systems. Some of them, founded on a mixed and uneven-aged forest structure (Meyer 1933, Susmel 1956), had already been applied in the past and never completely abandoned in some Alpine regions. The increasing spread of these systems, even if based on different theoretical and practical assumptions (Ciancio 2014), led to the progressive replacement, in many areas, of pure, even-aged structures by mixed, uneven-aged forests. This is also gradually changing, according to the long lifecycle of the trees, the appearance of the forest space in some European regions.

Despite the use of different raw materials such as plastic, iron, etc., the industrial roundwood removals, mainly used for the production of sawn-wood and wood-panels are still generally growing in the majority of European countries (Fig. 2). This suggests that, also from an economic point of view, this is still one of the most important functions provided by European forests.

\section{Non-wood products}

Forests also provide other non-wood forest products (NWFP), i.e., "goods of biological origin other than wood", including both plants and plant products (different from wood), animals and animal products (FAO 2005). Some of them, such as resin or straw, were widely harvested in the past, but are today only a marginal product. Others, such as cork (mainly in Southern European countries), pine nuts (INC 2016) or mushrooms, are still economically important.

In the past, forests resources were also widely used as food for humans and livestock. Chestnuts were an essential resource for mountain villages (Braudel 1979), while acorns and other minor forest species were, and in some cases still are, a fundamental feedstock for pigs and other animals (Pistorius et al. 2012). This last use 
of forest resources, for pig feeding or cattle grazing, is a typical example of the possible competition between different forest services. For this reason grazing, inside the forest area, was mentioned in the ancient Latin legislation and strictly regulated by Venetian law, as in all modern forest legislations (Di Bérengher 2010).

\section{Fuelwood production}

Humans have controlled fire at least since the Middle Pleistocene, 0.5 million years BC, and this gave them important benefits such as warmth, light and cooking (James et al. 1989), indirectly favoring social activities and allowing pastures, cropland and settlements to be enlarged through the slash-and-burn technique.

Of course, where existing, the forest is the place where wood for fuel can be more easily harvested, both as dead wood and as living biomass. This function was so important that, for reducing possible competitions between the use of wood for energy and for other products, the Latin law had already distinguished some forests to be used for fuelwood, named cedui (i.e., coppices, in current silvicultural practice) and for other products ( $\mathrm{Di}$ Bérengher 2010). As highlighted in Fig. 1 (see arrow " $A$ " on the right), this was, and still is a relevant topic in forest management, above all considering the current challenges linked to forest carbon storage (Pilli et al. 2015) and the increasing consumption of wood pellets within the European Union (Jonsson \& Rinaldi 2017).

The use of timber promoted since the $19^{\text {th }}$ century by modern forest science also sometimes had an indirect impact on local fuelwood production. In some cases, the broadleaves and other minor species used for fuel were replaced by conifers used for industrial roundwood production or the coppice system, a management system mainly designated to the production of fuelwood, was converted to a high forest. In other cases the same geometrical order promoted by modern forest science was applied to the existing coppice system, and this modified not only the material space, but also the representation of the space (i.e., the way we think and represent a space), that was carefully mapped and described to support the application of more strict regulations. This sometimes limited the previous rights to collect fuelwood for the use of local communities.

Charcoal production is also strictly linked with the use of wood for fuel. Its use is documented since the $3^{\text {rd }}$ millennium $B C$ and Theophrastus, in the $4^{\text {th }}$ century BC, described the carbonization process in detail (Agnoletti \& Anderson 2000). Largely used by both Greeks and Romans, charcoal continued to be produced from wood until the $19^{\text {th }}$ century, when it was gradually replaced by coke. In some regions, however, such as in Sardinia, this production was still common until the middle of the $20^{\text {th }}$ century (Scotti \& Cadoni 2007).
As shown in Fig. 2, the use of fuelwood generally declined after the Second World War after being largely replaced by fossil fuels in all European countries. Even if, during the 1970s, this negative trend gradually stopped due to the 1973 Oil Crisis, the decline also had an impact on the forest space. This was especially evident in areas where coppices were widespread (i.e., in the Apennines or Pre-alpine regions), modifying the structure of these forests. As these grew older, they assumed the aspect of an abandoned high forest. This, for example, is the case for many Italian beech coppices that had often been used in the past for fuelwood and charcoal production and were progressively abandoned in the 1960 s because of the spread of other energy sources and the depopulation of mountain areas (Nocentini 2009). These forests "naturally" converted to high forests because of an ageing process that prevents a further coppicing of the trees. They are today, de facto, "unmanaged" and do not have any specific "function". Moreover, large areas that had been previously recovered forest and were cultivated or leased for grazing, are now abandoned. This phenomena occurred in particular on the mountains of southern Europe (Kuemmerle et al. 2016). This opens an interesting debate in academic circles, on the possible future roles of these forests. In the last decades, the use of fuelwood has progressively increased in many European countries and many studies forecast a growing demand of wood for energy in all developed countries in order to reduce the impact of carbon emissions from fossil fuels (Mantau et al. 2010). A particular aspect to consider has been the gradual but significant use of fuelwood and pellets in domestic heating (Pra \& Pettenella 2016), partly as a result of rising coasts of fossil fuels and tax incentives (especially in the early $21^{\text {st }}$ century) and partly because of a cultural attraction for the "gentle heat" from fireplaces in modern homes. This suggests that, in Europe, the production of fuelwood is still, and will remain, a relevant forest function, still, potentially competing also with the timber production (Jonsson \& Rinaldi 2017).

\section{Soil-conservation}

As indicated by Williams (2000), deforestation was one of the key processes in the history of the human transformation of the Earth. Since the establishment of the first agricultural societies, in the Mesopotamia region, the slash-and-burn technique has been widely used to create croplands and (later on) pastures (Diamond 1997). Indeed, man understood quite early that the forest soil may be easily cultivated, because of the richness of soil nutrients (in fact the CICES classification system explicitly mentions the pedogenesis process as a regulation and maintenance service) and, even if it is still difficult to quantify the prehistoric clearing, it was certainly not negli- gible (Williams 2000). In the Mediterranean Classical world, clearing was so common that, in the $9^{\text {th }}$ century BC, Homer compared the noise of battle with "the crashing sound where woodmen fell the trees" (Williams 2000).

Unlike other forest functions, the acquisition of land through deforestation excludes any other services provided by the forest, since this is generally a permanent land use change. Moreover, and especially under Mediterranean conditions with their characteristic water erosion, high temperature and shallow soil depth, the soil deprived of its tree cover is quickly degraded (Don et al. 2011). Therefore, historically, competition with the protective function was (and may still be) the most relevant one (see arrow "B" in Fig. 1).

In general, deforestation has increased proportionally with population density and food demand in all human societies, and has substantially altered the European landscape until the Industrial Revolution (Kaplan et al. 2009). This process could be reversible under favorable climatic conditions, thus a population decline could result in a new forest expansion as was reported after the collapse of the Roman Empire in the $5^{\text {th }}$ century or the so-called Black Death in the $14^{\text {th }}$ century (Kaplan et al. 2009). In Central and Northern Europe the use of forest as soil-source has not generally been in competition with other functions. This is due to the relatively large forest area compared with the population density and demand for arable lands despite a local reduction in forest area. From the $15^{\text {th }}$ century, however, in some European regions, such as in the Mediterranean area, where high population density coexisted with particular morphological conditions, the loss of forest cover produced the first hydrogeological problems. This is the case of the Pre-Alpine territory of the Venice Republic, where a specific law promulgated by the Venetian Senate in 1530 tried to limit deforestation, in order to prevent possible landslides and water erosion phenomena and to ensure timber supply (Susmel 1994).

From the $19^{\text {th }}$ century, the steady growth in timber demand and the spread of new silvicultural practices gradually reduced deforestation in Europe. Due to the economic and social changes after the Second World War, marginal croplands and pastures were abandoned. This led to a continuous and large forest expansion, especially in Mediterranean countries, where the total forest area grew from about 51 million ha in 1990 to 61 million ha in 2010 (State of Europe's Forests 2015).

Clearly, any kind of deforestation has a direct impact on the forest space. First, because of the substitution of a closed space covered by trees, with an open space, possibly covered by other plants or used for settlements. This also has an effect on the representation of the space: a deforested area is generally easier to map, enter and 
study and other natural resources may be discovered. Moreover, it may trigger a feedback process that can further alter the remaining forested area: a new road through a natural forest may open the door to new villages, secondary roads, pastures or plantations (fishbone deforestation pattern) which can modify the local economy and change the cultural relationship between the local community and the forest. Since deforestation also implies the release into the atmosphere of the carbon stored by the trees, this function is also strictly related (see arrow "C" in Fig. 1) with the role of the forests in the carbon cycle and will be further discussed under this service.

\section{Cultural function}

The Celts in the German area, and the Greeks and Romans in the Mediterranean area, perceived nature, and in particular forests, as a realm of divinities. As testified by Brelich (2013) forested areas were (or, in some cultures, are) special places for initiation rites and ceremonies. Apart from the numerous examples of tree worship (dendrolatry) reported since the Paleolithic (Frazer 1922), in the Greek pantheon many divinities, such as Dionysus, had a particular relation with the forest space. The stone columns used in the temples represented the structure of a tree (Paci 2002). In the Latin tradition, forests reserved for activities of worship, named luci, were subject to specific management rules (Di Bérengher 2010).

Instead, due to the spread of Christianity, the collapse of the Roman Empire and the abandonment of croplands during the Middle Ages, the forest became a dangerous and "dark" place, as defined by Dante Alighieri at the beginning of his Commedia ("una selva oscura"). Because Pagan worship generally survived in marginal and forested lands, so did the attitude of the new, dominant, Christian culture towards the forests change radically. A conflicting perception appeared from the $11^{\text {th }}$ century when religious communities started to consider the forest as an additional value, to guarantee not only the revenues of the monastery, but also the silence and stillness that was essential for praying (Romano 2010). In this respect, we can mention the experience of Camaldoli or St. Francis of Assisi's attitude to nature and his retirement at La Verna (Central Italy). As a consequence, a new sacralizing of the forest space was promoted, through crosses and capitals dedicated to the Virgin Mary and other Christian saints, often replacing preexisting Pagan religious markers.

Starting from the $12^{\text {th }}$ century, together with the economic and demographic growth, man's approach towards nature also gradually changed. This led to new attitudes to and curiosity about forests. They became a shelter, such as for "El ingenioso hidalgo don Quijote de la Mancha" or a place of pleasure, where man escapes the rules imposed by society, such as in some of Shakespeare's comedies (Paci 2002).

With the Renaissance, man's attitude changed again and, adopting an external perspective, nature became an object at the disposal of humans (Farcy \& Devillez 2005). The Renaissance gardens, with their geometric order and the use of ars topiaria, well express this desire to shape nature and reduce it to fit the human project.

During the Age of Enlightenment, scientific knowledge increasingly affected man's attitude towards nature. The direct consequence of this new approach, which dominated all of Europe until the middle of the $20^{\text {th }}$ century, was not only the attempt to convert natural forests into a geometrically-designed landscape aimed to maximize the economic yield, but also a powerful aesthetic stereotype. The visual sign of well-managed forests was, and sometimes still is, regularity and neatness (Scott 1998). This new landscape pattern also changed the common aesthetic perception of the forest space and within a few short decades, at least in some areas, the collective memory had forgotten the pre-existing appearance of forests and accepted this artificial space as a "natural" and wellmanaged landscape (Schulze \& Schulze 2010). The reaction to this artificial view is given by Romanticism, which rediscovered the charm of the forest through Grimms' fairytales, Caspar's paintings, and the artificial, but similar to nature, structure of the Romantic garden (Paci 2002). As clearly highlighted by Schelling, nature becomes an unconscious expression of the spirit that could no longer be explained with the simple mechanistic approach proposed by science (Schelling 1797).

The radical simplification of the forest ecosystem imposed by the predominant forest science started to show its limitations after the First and, above all, the Second World War, when, due to different biological reasons, the productivity of the new forests that were often established during the previous century, gradually declined (Scott 1998). This forced forest scientists to review their production-oriented approach (Ciancio 2014), also taking into account the new needs emerging in many European countries. The economic and social changes after the Second World War introduced the idea that the forest space should also satisfy new demands, related to recreational activities, as requested by a society where increasing numbers of inhabitants left rural and mountain territories to live in urban areas. As an answer to these new requirements, new close-to-nature management methods were developed (Johann 2007) and specific forested areas were included in natural parks, tourist itineraries and viewpoints, specifically reserved for these activities.

Unlike the productive function, the benefits provided by the recreational function are not strictly limited to a specific forest owner but involve a considerably wider au- dience, including visitors or even those who benefit from a view of this landscape. Indeed, apart from possible debates on the naturalness of the European landscape, largely modified by centuries of human activities, we can state that the landscape is also part of the recreational forest function. Taking this aspect into account, since the beginning of the $20^{\text {th }}$ century, the legislation of some European countries such as Italy has provided specific recommendations in order to preserve the landscape function of forested areas (Ceruti 2006).

Since in many cases, the areas richer in biodiversity are also preferred by people for recreational activities, this function is clearly linked to (and sometimes in competition with) the biodiversity function (see arrow " $D$ " in Fig. 1).

A specific and recent development concerns the transformation of the forest space into "adventure parks", i.e., with the construction of suspended equipped paths. Visitors are offered a radically different view of the forest from above or even from the treetops.

Of course all these cultural services not only have a direct effect on the material space and on representation of the space, but even more on the space representation, since they are strictly linked to the emotions and sensations produced by the forest. From this point of view, the recreational service requested from the forest is not so different from the silence and stillness sought by the monks in the $11^{\text {th }}$ century. When people living and working in urban areas move to mountain and forested areas, they look for some cultural and spiritual benefit. The appearance of the socalled "new rurals" in recent years, i.e., people who return to live and work in mountain areas, perhaps devoting themselves to niche and certified products, integrated with sustainable tourism activities, is part of the same phenomena (Dematteis 2011). Many studies suggest that exposure to a forest environment reduces the stress induced by modern society and has a restorative function (Kaplan 1995, Shin et al. 2012). As suggested both by the Millennium Ecosystem Assessment (MA 2003, 2005) and the CICES classification system (Haines-Young \& Potschin 2011), we can therefore include the recreational function under a broader cultural service provided by the forest and defined as "nonmaterial benefits people obtain from ecosystems through spiritual enrichment, cognitive development, reflection, recreation and aesthetic experiences".

\section{The protective function}

This function, classified as a regulation and maintenance theme according to the CICES (Haines-Young \& Potschin 2011), includes the direct protection of the soil from wind and water erosion (i.e., an hydrological protection), the indirect reduction of avalanches and landslides and other additional effects due to the tree cover, 
such as the capacity of roots and leaves to reduce pollutants.

As a consequence of the strong reduction of the forest surface that occurred in some European regions, namely after the $14^{\text {th }}$ century in mountain areas, the protection guaranteed by forest cover decreased dramatically. This pushed the authorities, such as the Venetian Senate in 1598 , to promulgate specific laws aimed at protecting mountains from further deforestation. These same principles also inspired the socalled Colbert's Ordinance (also known as "l'aménagement forestier"), disseminated in France in 1669 by the Minister of Finances of Louis XIV. This was the first real forest code applied in France and had the purpose of halting the loss of forestry cover by regulating forest practices (Tissot \& Kohler 2013). Even if, in both the Venetian and French cases, these laws did not have the expected effect, they clearly testify to the importance attributed by public authorities to the protective function provided by forests and its strict link with deforestation. That same awareness inspired the Austro-Hungarian legislature when, in 1852, it distinguished the forests providing a specific protective function, generally on high slopes, from other forests (Johann 2007). In this, such as in other similar cases, the material dimension of the space, i.e., the identification of a specific forest, with the representation of this space through maps and markers, is an essential pre-requisite to translate the recognition of different functions into specific silvicultural practices. These may include taller stumps left after felling the trees in order to reduce avalanches on a mountainside, or a forested belt to prevent possible flooding and coastal erosion along a coastline,.

These principles, largely recognized by modern forest science, were already known to foresters, at least in those territories where, due to specific morphology, the protective function was a useful service provided to society. In other places however, these benefits could have been ignored or not adequately recognized because of the different morphological conditions. This may be the case of Finland where the protective function, as other non-productive functions, was not considered by the local legislation until the last decades of the $20^{\text {th }}$ century, when the multi-functionality of forest resources was explicitly recognized (Kotilainen \& Rytteri 2011).

It is known that the protective functions provided by forests is today widely recognized and guaranteed by the current legislation in all European countries, where about one-fifth of the total forest area is reported "to serve the protection of water supplies and the prevention of soil erosion" (State of Europe's Forests 2011). The fact that the benefits provided by this function affect an area considerably larger (i.e., at least the catchment area) than the specific forest surface justifies the limits im- posed by public authorities on the private forest owners, and this also applies to the biodiversity and carbon-retention functions considered below.

\section{Biodiversity as a forest function}

The report of the United Nations Conference on Environment and Development, held in Rio de Janeiro in 1992, declared that "The vital role of all types of forests in maintaining the ecological processes and $[\ldots]$ in protecting fragile ecosystems [...] and as rich storehouses of biodiversity and biological resources [...] should be recognized" (United Nations Conference on Environment and Development - UN 1992). This statement, along with the general conclusions of the Rio conventions, opened the door to official recognition of the role of forests as storehouses of biodiversity. The legal and management consequences following from this awareness, were strengthened by a series of other international agreements, such as the Helsinki Conference in 1993, the Lisbon Conference in 1998 and the Vienna Conference in 2006 (State of Europe's Forests 2011). Since the richness of biodiversity and its protection are commonly considered as a benefit that fulfills a societal demand, according to Dietrich's definition, this may be seen as an additional function performed by forests. The recent CICES classification system mainly included these services under the "regulation of biotic environment", further including lifecycle maintenance, habitat protection and gene pool protection (Haines-Young \& Potschin 2011).

The root of this function, however, does not lie just in the $20^{\text {th }}$ century's attention to environmental problems. Indeed, looking back to the original meaning of the word "forest", from the Medieval Latin forestis silvae, we see that this word was not strictly related to a wooded area, but to a banned area, reserved for hunting (Urbinati 2009, Romano 2010). Medieval society was fully conscious of the forest richness in biodiversity, even if this interest was limited mainly to the game, and the benefits were generally reserved for the noblemen (Farcy \& Devillez 2005). In some cases, we may even identify a direct link between those banned areas and the current environmental measures. For example, the first Italian national park (the Gran Paradiso National Park) was established in 1922 on the same area where the Italian king, Vittorio Emanuele II, had instituted a royal hunting ground in 1856 (Framarin \& Peracino 1982). The original purpose of this area was to preserve the Alpine ibex (Capra ibex L.) from possible extinction. And indeed, as a direct consequence of this ban, this species was actually spared from the extinction. Although in our society, hunting is still a recreational activity, the purpose of modern nature reserves is not to preserve one species for hunting, but the ecosystem and its biodiversity (even if, at times, focusing on some particular species), thus providing benefits for the entire society.

The benefits provided by this function may affect an area considerably bigger than the forest itself. Indeed, if for the hydrogeological function the catchment area is the area that benefits from the tree cover, the area where large mammals, such as bears, wolves or lynxes move, is considerably bigger and may even transcend national borders (Wotschikowski \& Heidegger 1994). During the last decades European countries have thus instituted a network of legally protected areas (also promoted by the Natura 2000 network), which often include forested areas, in order to ensure the species conservation, dispersal (also from a genetic point of view) and migration (European Union 2013). Thanks to these legal constraints, about $10 \%$ of European forests (excluding Russia) are currently protected, with the main objective of promoting biodiversity (State of Europe's Forests 2011). If we consider that the concept of "sustainable forest management", as defined by the Helsinki Conference in 1993 (Second Ministerial Conference on the Protection of Forests in Europe 1993) and applied to the majority of European forests, explicitly mentions the conservation of biodiversity, we can conclude that this is one of the main functions attributed to forests in Europe. As for the protective function, since harvesting and recreational activities may not always be compatible with the conservation of some species, this function may also be in competition with other services provided by forests (see arrow "D", in Fig. 1). In some cases, this might justify the exclusion of harvesting, hunting, or tourist access from a forest area, but it also opens an interesting debate on the possible approaches to integrate forest management and nature conservation. Whereas in a "segregation approach", nature conservation is limited to protected forest areas, in an "integration approach", nature conservation coexists with economic and social objectives in the same area (Boncina 2011). Apart from this debate, we can conclude that this function had in the past, through the Medieval banned areas, and still has through the modern protected areas, a direct effect on the production of space. We experience the presence of natural parks and reserves in the material space every day, made evident by signs in the field and in the representation of the space on our maps. Overall, these signs make clear the limitations imposed by the biodiversity function on the other competing services provided by the forests.

\section{The carbon-retention provided by} forests

Nineteen ninety-two was a milestone also for recognizing the role of forests with respect to the emerging climate change challenges, as carbon reservoirs and sinks. Indeed, in that year, the objective of stabilizing the greenhouse gas concentration in 
the atmosphere was officially assumed by the United Framework Convention on Climate Change (UNFCCC 1992). Article 4 of the Convention commits the Parties (i.e., the countries subscribing the document) to implement the measures to mitigate climate change by addressing emissions by sources and removals by sinks (UN 1992). The role of forests, only implicitly mentioned in this document, was explicated in 1997 by the Kyoto Protocol where article 3 commits the Parties to quantify the net changes in greenhouse gas emissions by sources and removals by sinks resulting from forestry activities, included deforestation (UN 1997). Starting from this document, a long series of further international agreements attributed an increasing role in the international climate change negotiations to forests (Höhne et al. 2007). This role is mainly related to the amount of carbon stored by forest ecosystems (both in living biomass and in dead organic matter and soil) and removed from the atmosphere as carbon dioxide through photosynthesis. Due to the increasing importance of these issues, this is currently one of the most prominent services attributed to the forest ecosystem, also explicitly recognized by the CICES as part of the regulation and maintenance service (Haines-Young \& Potschin 2011). Given that deforestation is the second largest anthropogenic source of carbon dioxide to the atmosphere, after fossil fuel combustion (Van Der Werf et al. 2009), the competition existing between this function and the carbon-retention function is clear (see arrow " $C$ " in Fig. 1). In particular, converting the forest area to other land uses, the carbon stored by soil and living biomass will be released into the atmosphere. For this reason, since the Thirteenth Conference of the Parties (COP13) promoted by UNFCCC, a number of countries developed strategies for Reducing the Emissions from Deforestation and Forest Degradation (i.e., the so-called REDD+ activities - Murdiyarso et al. 2012).

Through the promotion of specific silvicultural treatments, human activities may also increase carbon removal from the atmosphere. Furthermore, if we consider that part of this carbon may be even stored outside the forest area as harvested wood products or used as fuelwood instead of fossil fuels (Pilli et al. 2015), we understand the complex and sometimes competitive interaction (Nabuurs et al. 2015), that exist between the carbon-retention service and other productive functions (see arrow "E" in Fig. 1),

Beyond this narrow interaction with the productive function, this service is also characterized by the large spatial scale. While the benefits provided by other services may affect an area considerably larger than the forest itself, in this case, since the atmospheric system is global, the effects (positive or negative) provided by each forest parcel on this system will extend to a global scale. Of course, our senses do not have a direct perception of this effect because the material space is generally not directly modified by this function. This is a consequence of the fact that forests store and adsorb atmospheric carbon dioxide independently of human activities. However, because these activities can improve this capacity, even the carbon-retention function can in some cases modify the material space. This, for example, is the case of activities such as the so-called Clean Development Mechanisms promoting the afforestation or reforestation (IPCC 2003) of non-forested lands with the purpose of storing atmospheric carbon dioxide in the trees or using the woody biomass for energy in order to reduce fossil fuel consumption. The Short Rotation Forests (SRFs), planted on cropland and pastures using fast-growing tree species, have the specific purpose of producing fuelwood. In some European countries, such as in Ireland, the afforestation that occurred during the last decades has considerably modified the material space, increasing the total forest area by $19 \%$ since 2000 (O'Leary et al. 2000, State of Europe's Forests 2015). Of course, this will also have a direct effect on the representation of the space in the same areas.

Subscribing to both the UNFCCC and the Kyoto Protocol, all European countries and the European Union itself, with a specific internal legislation, have officially recognized the carbon-retention function provided by forests. For this reason, the estimate of the carbon stored, removed from or released to the atmosphere by forests, and the rules to account these amounts, are of crucial interest from both a political and scientific point of view (Grassi et al. 2010, European Commision 2016). A particular representation of the forest space, strictly linked to the need to quantify the carbon-retention capacity of the forests and correctly implement these rules, is the virtual representation of the forest parcels through forest growth models. The purpose of these models is to estimate the past, current and, above all, future carbon sink of the forests, through different approaches, based on remote sensing and/or field measurements. In many cases, they provide a spatially-explicit or simply a mathematical representation of the forest space (i.e., of each forest parcel - Kurz et al. 2009), which may be considered as a particular, virtual, representation of the space, strictly linked to this forest function.

\section{Discussion and conclusions}

Overall we highlighted that the use of forest resources changed over time, according to different social needs and different functions which have also been projected into different forms of conceiving, building and living the forest space. Even if, in the past such as in the present, the timber and fuelwood production was the most important function provided by wooded lands, other functions were also attributed to for- ests. In most cases, the awareness of these functions emerged when an overexploitation of forest resources produced a lack of a specific service. In these cases, to limit the competition with the predominant productive function, these additional services were explicitly recognized and regulatory, such as for the same cedui reserved for fuelwood production or the luci mentioned in the Latin tradition, or the banned areas in the Medieval society and the various legislatives intervention to limit deforestation. Today, due to the increasing complexity of the social needs, these functions coexists with more recent recreational and ecological services. Due to the strong, and in some cases competitive, interactions between these services, a different, multi-functional view of the forest resources has to be considered. Indeed, timber production may compete with fuelwood production; overall the productive function may be in competition with the other functions but it may even increase the amount of carbon, by storing the carbon removed by the atmosphere as harvested wood products or replacing fossil fuels with fuelwood. Of course, all these services generally disappear when, through deforestation, the original forest cover is replaced by other land uses, but reforesting the same area with fast-growing tree species, we may even increase the material production. The cultural function, including the modern recreational service, may be in competition both with the biodiversity function, since excessive human pressure can damage some protected species, and with the protective function. Indeed, replacing a forest with a ski run will eliminate the tree cover protection on the soil.

These strict interactions between different functions may be also recognized in the production of space, considered under different and sometimes overlapping dimensions and under a diachronic perspective. A forest parcel assigned to a productive function is a material space, marked in the field by colored signs affixed on the stems and represented through a forest map, which is part of a forest management plan. But that same parcel may be included in a protected area, made evident by signs in the field limiting hunting activities. If it is located on the top of a mountainside, some legal constraint, reported in the forest management plan, can impose specific silvicultural rules in order to reduce possible avalanches. In the meantime, since this parcel is always adsorbing atmospheric carbon, it may be virtually represented by a forest growth model to estimate the value of the carbon credits generated over time. Finally, if the same place is located near a viewpoint, it will produce some positive emotion in the people visiting the forest. Of course this picture would change if, instead of looking at the present, we consider the past. The same forest parcel was probably used for wood production even in Medieval times, but instead of the colored 
signs affixed on the stem, the property was probably bordered by stones or by some big tree and, instead of modern signs marking the presence of a natural park, some other sign would advise people that this was a banned area, reserved for hunting by the local nobility. Lastly, instead of the positive sensations produced in $21^{\text {st }}$ century man, Medieval people could have experienced fear and anxiety crossing the forest alone, knowing that it was frequented by wolf packs and bandits. But these aspects, strictly linked to the emotions, imaginations and sensations produced by the space, i.e., related to the space of representation, need to be further investigated in a specific research.

Due to the rapid changes during the last decades, a relatively short period if compared with the average lifecycle of the trees, some of the functions historically attributed to the forest need to be reconsidered. This is the case, as already mentioned, of coppices abandoned because of the decline of fuelwood and charcoal production. These forests, not subject to any direct management activity for some decades, continue to provide a protective service, through the tree cover of the soil, and a biodiversity service, since the abandonment of these areas indirectly promoted the spread of some species, such as the wolf on the Apennines (Fabbri et al. 2007). Although it appears that they do not perform any productive function, if properly measured, the carbon stored by these stands can be accounted as a carbon-retention. This helps us to differentiate between the concept of function and "good" (i.e., the things which people value) on the one hand, and services (i.e., the things which ecosystem generate) on the other (HainesYoung \& Potschin 2011). Even if both these concepts are inherently anthropocentric (De Groot et al. 2002), the historical perspective proposed by our analysis highlights that all forests, including abandoned coppices, provide some potentially useful service, such as protecting the soil or biological resources. But only when these services correspond to a societal demand, they produce welfare benefits for society, which are recognized as forest functions and can generate goods that people value. In the specific case of the carbon-retention service, the link between the service and the corresponding societal demand is recognized also by the current international agreements. Indeed, according to these rules, only the additional amount of carbon saved by forests, due to human activity, can be accounted as a useful effort to mitigate climate change and under particular conditions, has an economic value (IPCC 2003, Höhne et al. 2007). Evaluating, from a correct historical perspective, when each societal demand emerged, and was consequently taken into account by forest management, is essential. So, for example an ex-post evaluation of the "role" of forest management to mitigate climate warming in the last centuries, as was recently proposed by Naudts et al. (2016), could be criticized if implicitly attributing to forest management a function that was only recognized few decades ago (Pilli 2016).

Not only the temporal awareness but also the spatial scale of each service can change considerably. The benefits vary from the specific forest area and its owner, for the productive functions, to the catchment area and its inhabitants, for the protective function, to a potentially larger area and number of people, for the cultural and biodiversity services and, finally, to the entire globe, for the carbon service. This spatial overlap between different and partially competing functions and services may not only justify the limits imposed by public authorities on the private owners and management of these forests, but also the payment for some ecosystem service without a direct market value, such as carbon sequestration (Pistorius et al. 2012).

The complex interactions between different functions and spatial dimensions justify the need to develop an integrative, multifunctional forest management system balancing a segregative approach with a wider integrated management system (Kraus \& Krumm 2013). The first one, if strictly applied, allocates a certain amount of forests for natural conservation, maximizing the commodity production in the remaining landscape. The integrative approach aims to combine different forest functions across the total forest area. Taking into account the historical evolution of European forests, as highlighted by our analysis, a balance is needed between these two approaches. This means that, some areas have to be strictly reserved for specific forest functions, such as a productive function (e.g., SRFs), or to provide a protective (e.g., in mountain regions), cultural (e.g., near a monastery), or biodiversity service. But the majority of the forest area has to be managed through an integrated approach, combining, even if within a difficult equilibrium (Schulze \& Schulze 2010), different forest functions in a way that maintains the biodiversity, the productivity and the regeneration capacity of forest resources, and their potential to fulfill, now and in the future, the relevant ecological, economic and social functions, at local, national and global levels (FAO 2016). As highlighted by our study, to reach this difficult equilibrium it is even useful to consider the production processes of these forest spaces. Through this analytical key we can also understand the interaction that has occurred over time between the evolution of the demands expressed by the society and the main changes occurred on the forest landscape. Referring to present and future functions, the above-mentioned definition of Sustainable Forest Management, implicitly takes into account a historical perspective: as these functions and services changed in the past, they could also change in the future.

\section{Acknowledgments}

We sincerely thank Ola Sallnäs, from the Swedish University of Agricultural Sciences (Sweden), for the useful suggestions and information provided on the historical forest management practices in Scandinavian countries; Davide Pettenella, from the University of Padova (Italy), Sarah Mubareka, from the Joint Research Centre (Ispra, Italy) and two anonymous reviewers, for the useful comments and suggestions provided on the overall manuscript. We also thanks professor Bernardo Hellrigl, from the University of Padova, for the precious stimulus arising from his oral relation on the "Dendroenergy" (San Vito di Cadore, 47 June 2007, Italy).

The views expressed are purely those of the authors, and may not under any circumstances be regarded as stating an official position of the European Commission.

\section{References}

Agnoletti M, Anderson S (2000). Methods and approaches in forest history. IUFRO Research Series 3, University Press, Cambridge, UK, pp. 281. [online] URL: http://books.google.com/ books?id=97gyRl20xxEC

Allen R (2009). The british industrial revolution in global perspective. Cambridge Press University, Cambridge, UK, pp. 344. [online] URL: http://www.britac.ac.uk/sites/default/files/pba1 67p199_0.pdf

Boncina A (2011). Conceptual approaches to integrate nature conservation into forest management: a Central European perspective. International Forestry Review 13 (1): 13-22. - doi: 10.1505 /146554811798201152

Braudel F (1979). La Méditerranée et le Monde méditerranée à l'époque de Philippe II [The Mediterranean and the Mediterranean World in the Age of Philip II]. IV Edition, Librarie Armand Colin, Paris, France, pp. 160. [in French]

Brelich A (2013). Paides e Parthenoi. Primo volume [Paides and Partenoi. First volume] (Alessandri A, Cremonesi C eds). Editori Riuniti, University Press, Roma, Italy, pp. 518. [in Italian]

Brenner N, Elden S (2009). Henry Lefebvre on state, space, territory. International Political Sociology 3: 353-377. - doi: 10.1111/j.1749-5687.20 09.00081.x

Cacciavillani I (1984). Le leggi veneziane sul territorio, 1471-1789: boschi, fiumi, bonifiche e irrigazioni [Venetian laws on the territory, 14711789: forests, rivers, land reclamation and irrigation]. Signum, Limena (Padova), Italy, pp. 255. [in Italian]

Casti Moreschi E, Zolli E (1988). Boschi della Serenissima: storia di un rapporto uomo-ambiente [Woods of the Serenissima: story of a manenvironment relationship]. Arsenale, Venezia, pp. 132. [in Italian]

Ceruti G (2006). From the protection of landscape and "natural beauties" to the defense of ecosystem in Italy. In: "Nature Conservation. Concepts and Practice" (Gafta D, Akeroyd J eds). Springer, Berlin-Heidelberg, Germany, pp. 55-64. - doi: 10.1007/978-3-540-47229-2_5 Ciancio O (2014). Storia del pensiero forestale [History of forestry thought]. Rubettino, Catanzaro, Italy, pp. 543. [in Italian] 
De Groot RS, Wilson MA, Boumans RM (2002). A typology for the classification, description and valuation of ecosystem functions, goods and services. Ecological Economics 41 (3): 393-408. doi: 10.1016/Sog21-8009(02)00089-7

Dematteis G (2011). Montanari per scelta. Indizi di rinascita nella montagna piemontese [Mountaineer for shoice. Signs of rebirth in the Piedmont mountains]. FrancoAngeli, Milano, Italy, pp. 112. [in Italian]

Di Bérengher A (2010). Studii di archeologia forestale [Forestry archeology studies]. Firenze, 1965. Reprint from, Corpo Forestale dello Stato, Roma, Italy, pp. 600. [in Italian]

Diamond J (1997). Guns, germs, and steel. The fates of human societies. WW Norton and Company, New York, USA, pp. 480.

Don A, Schumacher J, Freibauer A (2011). Impact of tropical land-use change on soil organic carbon stocks- a meta-analysis. Global Change Biology 17: 1658-166o. - doi: 10.1111/j.1365-2486.20 10.02336.x

European Commision (2016). Proposal for a Regulation of the European Parliament and of the Council on the inclusion of greenhouse gas emissions and removals from land use, land use change and forestry into the 2030 climate and energy framework and amending Regulation No 525/2013 of the European Parliament and the Council on a mechanism for monitoring and reporting greenhouse gas emissions and other information relevant to climate change. European Commission, Brussels, pp. 37. [online] URL: http://ec.europa.eu/transparency/regdoc/ rep/1/2016/EN/1-2016-479-EN-F1-1.PDF

European Union (2013). Guidelines on Wilderness in Natura 2000. Document prepared with the assistance of ALTERRA in a consortium with PAN Parks Foundation and EUROSITE under contract to the European Commission, European Union, Luxembourg, pp. 98. [online] URL: http://ec.europa.eu/environment/nature/ natura2000/wilderness/pdf/WildernessGuidelin es.pdf

Fabbri E, Miquel C, Lucchini V, Santini A, Caniglia R, Duchamp C, Weber J-M, Lequette B, Marucco $F$, Boitani $L$, Fumagalli $L$, Taberlet $P$, Randi $E$ (2007). From the Apennines to the Alps: colonization genetics of the naturally expanding Italian wolf (Canis lupus) population. Molecular Ecology 16: 1661-1671. - doi: 10.1111/j.1365-294X. 2007.03262.x

FAO (2005). Proceedings of the $3^{\text {rd }}$ Expert Meeting on Harmonizing Forest-Related Definitions for Use by Various Stakeholders. Food and Agriculture Organization of the United Nations, Rome (Italy) 17-19 Jan 2005, pp. 148.

FAO (2016). Sustainable forest management. Food and Agriculture Organization of the United Nations, Rome, Italy. [online] URL: http:// www.fao.org/docrep/005/y4171e/y4171e49.htm FAOSTAT (2015). Home page. Statistics Division of the Food and Agriculture Organization of the United Nations, Rome, Italy. [online] URL: http://www.fao.org/faostat/en/\#home

Farcy C, Devillez F (2005). New orientations of forest management planning from an historical perspective of the relations between man and nature. Forest Policy and Economics 7: 85-95. doi: 10.1016/S1389-9341(03)00013-3

Filková V, Kolár T, Rybníček M, Gryc V, Vavrčik H,
Jurčik J (2015). Historical utilization of wood in southeastern Moravia (Czech Republic). iForest 8: 101-107. - doi: 10.3832/ifor1091-007

Framarin F, Peracino V (1982). Parco Nazionale del Gran Paradiso [Gran Paradiso National Park]. In: "Parchi e Riserve Naturali in Italia" (Bianchi E, D'Inella M, Laurini $M$ eds), Touring Club Italiano, Milano, Italy, pp. 253. [in Italian] Frazer JG (1922). The golden bough. Macmillan, New York, USA, pp. 607.

Gottdiener M (1993). A Marx for our time: Henri Lefebvre and the production of space. Sociological Theory 11: 129-134. - doi: 10.2307/201984 Grassi G, Federici S, Pilli R (2010). What happened to forests in Copenhagen? iForest 3: 3032. - doi: 10.3832/iforo529-003

Haines-Young R, Potschin M (2011). Common international classification of ecosystem services (CICES): 2011 update. European Environment Agency, The University of Nottingham, CEM, Nottingham, UK, pp. 17. [online] URL: http://test.matth.eu/content/uploads/sites/8/20 09/11/CICES_Update_Nov2011.pdf

Harvey D (2006). Space as a key word. In: "Spaces of Global Capitalism: Towards a Theory of Uneven Geographical Development" (Harvey D eds). Verso, London-New York, pp. 115-148.

Höhne N, Wartmann S, Herold A, Freibauer A (2007). The rules for land use, land use change and forestry under the Kyoto Protocol - lessons learned for the future climate negotiations. Environmental Science and Policy 10: 353-369. doi: 10.1016/j.envsci.2007.02.001

INC (2016). Global statistical review 2014-2015. International Nut and Dried Fruit, Reus, Spain. [online] URL: http://www.nutfruit.org/wp-cont inguts/uploads/2015/11/global-statistical-review2014-2015_101779.pdf

IPCC (2003). Good practice guidance for land use, land-use change and forestry. Institute for Global Environmental Strategies, Hayama, Japan, pp. 590. [online] URL: http://www.ipccnggip.iges.or.jp/public/gpglulucf/gpglulucf files /GPG_LULUCF_FULL.pdf

James SR, Dennell RW, Gilbert Allan S, Lewis Henry T, Gowlett JAT, Lynch Thomas F, McGrew WC, Peters Charles R, Pope Geoffrey G, Stahl Ann B (1989). Hominid use of fire in the Lower and Middle Pleistocene: a review of the evidence. Current Anthropology 3: 1-26. - doi: $10.1086 / 203705$

Johann E (2007). Traditional forest management under the influence of science and industry: the story of the alpine cultural landscape. Forest Ecology and Management 249: 54-62. - doi: 10.1016/j.foreco.2007.04.049

Jonsson R, Rinaldi F (2017). The impact on global wood-product markets of increasing consumption of wood pellets within the European Union. Energy 133: 864-878. - doi: 10.1016/j.ener gy.2017.05.178

Kaplan JO, Krumhardt KM, Zimmermann N (2009). The prehistoric and preindustrial deforestation of Europe. Quaternary Science Reviews 28: 3016-3034. - doi: 10.1016/j.quascirev. 2009.09.028

Kaplan S (1995). The restorative benefits of nature: toward an integrative framework. Journal of Environmental Psychology 15: 169-182. doi: 10.1016/0272-4944(95)90001-2

Kotilainen J, Rytteri T (2011). Transformation of forest policy regimes in Finland since the $19^{\text {th }}$ century. Journal of Historical Geography 37: 429-439. - doi: 10.1016/j.jhg.2011.04.003

Kraus D, Krumm F (2013). Integrative approaches as an opportunity for the conservation of forest biodiversity. European Forest Institute, Freiburg, Germany, pp. 284.

Krott M (2005). Forests policy analysis. European Forest Institute, Springer, Dordrecht, The Netherlands, pp. 334.

Kuemmerle T, Levers C, Erb K, Estel S, Jepsen MR, Müller D, Plutzar C, Stürck J, Verkerk PJ, Verburg PH, Reenberg A (2016). Hotspots of land use change in Europe. Environmental Research Letters 11 (6): 064020. - doi: 10.1088/ 1748-9326/11/6/064020

Kurz WA, Dymond CC, White TM, Stinson G, Shaw CH, Rampley G, Smyth C, Simpson BN, Neilson E, Trofymow JA, Metsaranta J, Apps MJ (2009). CBM-CFS3: a model of carbon-dynamics in forestry and land-use change implementing IPCC standards. Ecological Modelling 220: 480504. - doi: 10.1016/j.ecolmodel.2008.10.018

Lefebvre H (1974). La production de l'espace [The production of Space]. Anthropos, Paris, France, pp. 485. [in French]

Mantau U, Saal U, Prins K, Steierer F, Lindner M, Verkerk $\mathrm{H}$, Eggers J, Leek $\mathrm{N}$, Oldenburger J, Asikainen A, Anttila P (2010). EUwood - Real potential for changes in growth and use of EU forests. Final report, Hamburg, Germany, pp. 160.

May-Tobin C (2011). Wood for fuel, chapter 8. In: "The Root of the Problem" (Boucher D, MayTobin C, Lininger K, Roquemore S eds). Union of Concerned Scientists, Cambridge, UK, pp. 113. [online] URL: http://www.ucsusa.org/sit es/default/files/legacy/assets/documents/global _warming/UCS_RootoftheProblem_DriversofD eforestation FullReport.pdf

Meyer HA (1933). Eine Mathematische Untersuchung über den Aufbau des Plenterwaldes [A mathematical analysis of the structure of a Plenterwald]. Schweizerische Zeitschrift für Forstwesen 84: 33-46, 88 - 103: 124-131. [in German]

MA (2003). Ecosystems and human well-being: a framework for assessment. Millennium Ecosystem Assessment, Island Press, Washington DC, USA, pp. 266.

MA (2005). Ecosystems and human well-being: current state and trends. Findings of the condition and trends. Working group. Millennium Ecosystem Assessment, Island Press, Washington DC, USA, pp. 155.

Mokyr J (1992). The lever of riches: technological creativity and economic progress. Oxford University Press, Oxford, UK, pp. 368.

Mourre V, Villa P, Henshilwood CS (2010). Early use of pressure flaking on lithic artifacts at Blombos Cave, South Africa. Science 330: 659662. - doi: 10.1126/science.1195550

Murdiyarso D, Brockhaus M, Sunderlin WD, Verchot $L$ (2012). Some lessons learned from the first generation of REDD+ activities. Current Opinion in Environmental Sustainability 4: 678685. - doi: 10.1016/j.cosust.2012.10.014

Nabuurs G-J, Delacorte P, Ellison D, Hanewinkel M, Lindner M, Nesbit M, Ollikainen M, Savaresi A (2015). A new role for forests and the forest sector in the EU post-2020 climate targets. 
From Science to Policy 2. European Forest Institute, Joensuu, Finland, pp. 32. [online] URL: http://library.wur.nl/WebQuery/wurpubs/49508 3

Nadel D, Boaretto E, Werker E (2006). Wooden objects from Ohalo II (23,000 cal BP), Jordan Valley, Israel. Journal of Human Evolution 50 (6): 644-662. - doi: 10.1016/j.jhevol.2005.12.010 Naudts K, Chen Y, McGrath M, Ryder J, Valade A, Otto J, Lussayert S (2016). Europe's forest management did not mitigate climate warming. Science 351: 597-600. - doi: 10.1126/science.aad72 70

Nocentini S (2009). Structure and management of beech (Fagus sylvatica L.) forests in Italy. iForest 2: 105-113. - doi: 10.3832/iforo499-002

O'Leary T, McCormack AG, Clinch JP (2000). Afforestation in Ireland - regional differences in attitude. Land Use Policy 17: 39-48. - doi: 10.1016/S0264-8377(99)00036-8

Paci M (2002). L'uomo e la foresta [Man and Forest]. Meltemi, Roma, Italy, pp. 168. [in Italian]

Pilli R, Fiorese G, Grassi G (2015). EU mitigation potential of harvested wood products. Carbon Balance and Management 10 (1): 441. - doi: 10.1186/s13021-015-0016-7

Pilli R (2016). Europe's forest management did not mitigate climate warming: a correct historical perspective! Science, eLetters. [online] URL: http://science.sciencemag.org/content/351/627 3/597/tab-e-letters

Pistorius T, Schaich H, Winkel G, Plieninger T, Bieling C, Konold W, Volz K-R (2012). Lessons for REDDplus: a comparative analysis of the German discourse on forest functions and the global ecosystem services debate. Forest Policy and Economics 18: 4-12. - doi: 10.1016/j.forpol.20 11.09.001

Pra A, Pettenella D (2016). Consumption of wood biomass for energy in Italy: a strategic role based on weak knowledge. Italian Journal of Forest and Mountain Environments 71 (1): 49-62. - doi: 10.4129/ifm.2016.1.03

Rackham O (1986). The history of the countryside: the full fascinating story of Britain's landscape. JM Dent and Sons Ltd, London, UK, pp. 415.

Riegert C, Bader A (2010). German cultural history of forestry and forest functions since the early $19^{\text {th }}$ century. Web site. [online] URL: http://www.eoearth.org/view/article/152966 Romano R (2010). Codice Forestale Camaldolese. Le radici della sostenibilità. Primo Volume [Camaldolese Forest Code. The roots of sustainability. First Volume]. Ministero delle Politiche Agricole, Alimentari e Forestali, Osservatorio Foreste, INEA, Collegium Scriptorium Fontis Avellanae, Fano, Italy, pp. 250. [in Italian] [online] URL: http://dspace.inea.it/bitstream/ inea/454/1/vitaeremitica.pdf

Schelling FW (1797). Einleitung zu den Ideen zu einer Philosophie der Natur [Introduction to ideas for a philosophy of nature]. In: Preti G (1967). L'empirismo filosofico e altri scritti [Philosophical empiricism and other writings]. La Nuova Italia, Firenze, Italy, pp. 1-65.

Schulze EF, Schulze I (2010). Sustainable foresting: easier said than done. Science 327 (5968): 957. - doi: 10.1126/science.327.5968.957-a

Scott JC (1998). Seeing like a State. How certain schemes to improve the human condition have failed. Yale University Press, New Haven and London, UK, pp. 435.

Scott JC (2010). The trouble with the view from above. Web site. [online] URL: http://www.ca to-unbound.org/2010/09/08/james-c-scott/trou ble-view-above

Scotti R, Cadoni M (2007). A historical analysis of traditional common forest planning and management in Seneghe, Sardinia - Lessons for sustainable development. Forest Ecology and Management 249: 116-124. - doi: 10.1016/j.for eco.2007.05.027

Second Ministerial Conference on the Protection of Forests in Europe (1993). Resolution H1. General guidelines for the sustainable management of forests in Europe. Helsinki (Finland) 16-17 June 1993, pp. 5. [online] URL: http://www. foresteurope.org/docs/MC/MC_helsinki_resolut ionH1.pdf

Shin WS, Shin CS, Yeoun PS (2012). The influence of forestry camp on depression in alcoholics. Environmental Health and Preventive Medicine 17 (1): 73-76. - doi: 10.1007/s12199-011-0215-0

State of Europe's Forests (2011). Ministerial conference on the protection of forests in Europe 2011. Forest Europe Liaison Unit, Madrid, Spain, pp. 344.

State of Europe's Forests (2015). Ministerial conference on the protection of forests in Europe 2015. Forest Europe Liaison Unit, Madrid, Spain, pp. 314.

Susmel L (1956). Leggi di variazione dei parametri della foresta disetanea normale [Laws of variation of the parameters of the uneven-aged normal forest]. Italia Forestale e Montana 3: 105-116. [in Italian]

Susmel L (1994). I rovereti di pianura della Serenissima [Oaks woodlands of the Venetian plain]. CLEUP, Padova, Italy, pp. 159. [in Italian] Tissot W, Kohler $Y$ (2013). Integration of nature protection in forest policy in France. INTEGRATE Country Report, EFICENT-OEF, Freiburg, Germany, pp. 40. [online] URL: http://www.efi.int/ files/attachments/eficent/projects/france.pdf UN (1992). Agenda 21. United Nations Confer- ence on Environment and Development. Rio de Janeiro (Brazil) 3-14 Jun 1992, pp. 351. [online] URL: http://sustainabledevelopment.un.org/co ntent/documents/Agenda21.pdf

UN (1997). Kyoto Protocol to the United Nations Framework Convention on Climate Change. United Nations, New York, USA, pp. 21. [online] URL: http://unfccc.int/resource/docs/convkp/kp eng.pdf

UNFCCC (1992). United Nations framework convention on climate change. United Nations, New York, USA. [online] URL: http://unfccc. int/resource/docs/convkp/conveng.pdf

UN General Assembly (1992). Report of the United Nations conference on environment and development. United Nations Department of Economic and Social Affairs, Rio de Janeiro, Brazil. [online] URL: http://www.un.org/docu ments/ga/conf151/aconf15126-1annex1.htm

Urbinati C (2009). Foreste in forma. La gestione sostenibile nei boschi delle Marche [Forests in good shape. Sustainable management in the Marche forests]. Regione Marche, Comunitá Montana Alto e Medio Metauro e Partners, Arti Grafiche Stibu, Urbania, Italy, pp. 164. [in Italian]

Van Der Werf GR, Morton DC, DeFries RS, Olivier JGJ, Kasibhatla PS, Jackson RB, Collatz GJ, Randerson JT (2009). $\mathrm{CO}_{2}$ emissions from forest loss. Nature Geoscience 2: 737-738. - doi: 10.103 8/ngeo671

Williams M (2000). Dark ages and dark areas: global deforestation in the deep past. Journal of Historical Geography 26: 28-46. - doi: 10.1006 /jhge.1999.0189

Wing JT (2015). Roots of empire. Forests and state power in early modern Spain, c. 15001750. Brill, Leiden, Boston, USA, pp. 268. [online] URL: http://books.google.com/books? id=7dQuBgAAQBAJ

Wotschikowski U, Heidegger A (1994). Fauna e caccia sulle Alpi [Wildlife and Hunting in the Alps]. Athesia, Bolzano, Italy, pp. 184. [in Italian]

\section{Supplementary Material}

Tab. S1 - Summary of the production of space (i.e., the actions and representation on the forests) related to different forest functions and the consequent effects of these actions on the forest space (product space), highlighting the final change on the space appearance of the forest.

Link: Pilli_2316@supploo1.pdf 